\title{
$1: 65064007-65012229$
}

National Cancer Institute

\section{Source}

National Cancer Institute. 1:65064007-65012229. NCI Thesaurus. Code C44986.

Physical location of JAK1_Gene 